\title{
Variability and Genetic Advance for Seed Yield and its Components in Castor (Ricinus communis L.) Germplasm of CRIDA under Rain-Fed Conditions in Alfisols
}

\author{
P. Sowmya*, M. Vanaja, V. Sunita and P. Raghuram Reddy
}

ICAR-CRIDA-Central Research Institute for Dryland Agriculture, Santoshnagar, Hyderabad500059, India

*Corresponding author

\section{Keywords \\ Castor, Genotypes, Seed yield, Genetic variability, Genetic advance \\ Article Info \\ Accepted: \\ 14 December 2018 \\ Available Online: \\ 10 January 2019}

\section{A B S T R A C T}

Variability in seed yield of castor genotypes and its association between different yield contributing traits as well as genetic advance were studied during kharif-2012 with 23 CRIDA castor genotypes under rain-fed conditions in alfisols. Superior genotypes for yield and its components were identified. The variability for genotypes was significant for seed yield and all its four components studied viz., number of branches, number of nodes, capsule number and capsule weight. The correlation coefficient analysis revealed that seed yield was highly significantly correlated with capsule number and capsule weight. High heritability with high genetic advance as mean (GAM) was observed for capsule number, capsule weight and seed yield, there by revealing that selection for high capsule number and capsule weight will increase the seed yield in castor. Based on the seed yield performance, twelve genotypes which yielded above $63.57 \mathrm{~g} / \mathrm{pl}$ (average yield of 23 genotypes) were selected for further evaluation of physiological efficiency coupled with seed yield. It was observed that CRC-4 is the only genotype where in the range for five characters was 2-6 ranks, thereby revealing that this is a desirable genotype with higher ranks for all the five characters studied.

\section{Introduction}

Castor bean (Ricinus communis L.) is a tropical non-edible oil yielding plant of high commercial importance. Castor bean is a monotypic species belonging to the family Euphorbiaceae and has a wide range distribution in both tropical and sub-tropical regions (Dapke et al., 2016). India accounts for a total production of 17.33 lakh tonnes from an area of 11.05 lakh ha and a productivity of $1568 \mathrm{~kg} / \mathrm{ha}$ during 2014-2015 (Ramesh et al., 2016). Major castor growing countries include India, Brazil, China, Russia and Thailand (Nagesh Kumar et al., 2015). India is largest producer of castor seed and constitutes about $64 \%$ of total global production.

In India, Telangana and Gujarat are well known for castor production and productivity. To develop high yielding castor genotypes that 
get fit into the present cropping system, it is important to create the genetic variability for the selection of desirable variant. Castor being a deep rooted crop, it can extract water from considerable depth in the soil. In India castor is normally grown as rain-fed crop in both kharif and rabi seasons.

As seed yield is the principal factor and influenced by various characters directly and indirectly, hence it is essential to know the relationship between them in order to improve the yield potential through its components (Frageria and Kokli, 1997). In this direction, maximum utilization of the desirable characters for the development of an ideal genotype is important in castor (Halilu, 2013).

In castor, most of the yield characters are governed by quantitative genes which in turn influenced by environment. Thus, the efficiency of selection of castor becomes lesser with increase in environmental effects (Dhedi et al., 2010). In order to obtain accurate results, the genotypes of castor have to be evaluated over multilocations/seasons (Patel and Jaimini, 1988). Hence, it is necessary to evaluate the genetic variability present across Ricinus communis germplasm from different geographic regions (Hinckley, 2006). Thus, the identification of significant yield contributing parameters are necessary for improving the yield of castor and towards this endeavor, 23 genotypes of castor from CRIDA germplasm were evaluated at field conditions. This identification of better lines would be helpful in the process of improving castor productivity and production.

\section{Materials and Methods}

Four hundred accessions of castor germplasm were crossed for more than ten years during an Indo-U.S. project at CRIDA. During Kharif2012, a field study was conducted with twenty three CRIDA castor genotypes i.e., CRC-1,
CRC-2, CRC-3, CRC-4, CRC-5, CRC-6, CRC-7, CRC-8, CRC-9, CRC-10, CRC-11, CRC-12, CRC-13, CRC-14, CRC-15, CRC16, CRC-17, CRC-18, CRC-19, CRC-20, CRC-21, CRC-22 and CRC-23at Hayathnagar Research Farm, Central Research Institute for Dryland Agriculture (ICAR-CRIDA), Hyderabad, the trial was sown on July $14^{\text {th }}$, 2012 in RBD with three replications. During the crop growth period, the crop received 692 $\mathrm{mm}$ rainfall spreading in 36 rainy days $(>2.5$ $\mathrm{mm}$ ) and the crop experienced dry spell of more than 10 days during initiation to maturation of secondaries, and the rains stopped from initiation of tertiaries onwards to maturation of tertiaries.

The average temperature was $30.4^{\circ} \mathrm{C}$ with minimum and maximum of $15.2^{\circ} \mathrm{C}$ and $40.0^{\circ} \mathrm{C}$ respectively (Table 1 ). Each genotype was sown in $5 \mathrm{~m}$ length of three rows with plant to plant spacing of $30 \mathrm{~cm}$ and $1 \mathrm{~m}$ between rows. At the time of harvest, the observations were recorded on randomly selected five plants from each replication of individual genotype on number of branches up to primaries, number of nodes up to primaries, capsule number, capsule weight and seed yield of three spikes orders i.e., primaries, secondaries and tertiaries.

\section{Genetic analysis}

Heritability in broad sense $\left(\mathrm{H}^{2}\right.$ or $\left.\mathrm{h}^{2}\right)$ (Falconer, 1989)

Phenotypic and genotypic correlations (Miller et al., 1958)

Genotypic $\left(\sigma^{2} \mathrm{~g}\right)$ and Phenotypic variances $\left(\sigma^{2} \mathrm{ph}\right)$ (Comstock and Robinson, 1952).

Phenotypic Coefficient of Variation (PCV) and Genotypic Coefficient of Variation (GCV) (Singh and Chaudhary, 1985).

Statistical analysis - Analysis of variance (ANOVA)- STAR (Statistical Tools For Agricultural Research). 


\section{Results and Discussion}

Data on seed yield and its four components i.e., number of nodes, number of branches capsule number and capsule weight were recorded for 23 CRIDA castor genotypes for the three spike orders i.e., primaries (first order), secondaries (second order) and tertiaries (third order) during kharif-2012. The mean performance of all the components is presented in Table 2.

\section{Yield and its components}

\section{Seed yield (grams per plant-g/pl)}

The seed yield of 23 CRIDA castor genotypes ranged from $8.88 \mathrm{~g} / \mathrm{pl}$ (CRC-23) to 107.4 $\mathrm{g} / \mathrm{pl}(\mathrm{CRC}-1)$ with an average of $63.57 \mathrm{~g} / \mathrm{pl}$.

Number of nodes up to primaries (per plant-/pl)

The number of nodes ranged from 11 (CRC20) to 28.2 (CRC-17) with an average of $19.55 / \mathrm{pl}$. The genotype CRC-1 with high seed yield had 24.3 nodes.

Number of branches up to primaries (per plant)

The number of branches ranged from 2.79 (CRC-16) to 7.75 (CRC-22) with an average branches of 5.74 while CRC-1 recorded 5.56 branches.

\section{Capsule number (per plant)}

The capsules of three spike orders ranged from 26.50 (CRC-23) to 225.00 (CRC-5) per plant with an average of $117.13 / \mathrm{pl}$. The high yielding genotype, CRC-1 recorded 174.50 capsules /pl.

\section{Capsule weight $(\mathrm{g} / \mathrm{pl})$}

The capsule weight of the genotypes ranged from $15.00 \mathrm{~g} / \mathrm{pl}(\mathrm{CRC}-23)$ to $151.80 \mathrm{~g} / \mathrm{pl}(\mathrm{CRC}$ -
5) with an average of $94.01 \mathrm{~g} / \mathrm{pl}$. The high yielding genotype, CRC-1 recorded capsule weight of $150 \mathrm{~g} / \mathrm{pl}$.

\section{The Analysis of Variance (ANOVA)}

ANOVA showed highly significant variability $(p<0.01)$ among the genotypes for all the five parameters studied viz., number of branches, number of nodes up to primaries, capsule number/pl, capsule weight /pl and seed yield $/ \mathrm{pl}$ and presented in Table 3 .

\section{Correlations}

Correlation studies provide the association of seed yield with other traits. The genotypic $\left(\mathrm{r}_{\mathrm{G}}\right)$ and phenotypic correlations $\left(\mathrm{r}_{\mathrm{p}}\right)$ of all the five parameters are presented in Table 4. The $r_{G}$ and $r_{P}$ of seed yield was highly significantly and positively correlated for both capsule weight $(0.985 * *$ and $0.979 * *)$ and capsule number $(0.930 * *$ and $0.924 * *)$. Capsule weight and capsule number have also showed significant positive correlation with each other with $\mathrm{r}_{\mathrm{G}}$ of $0.965^{* *}$ and $\mathrm{r}_{\mathrm{P}}$ of $0.959 * *$ respectively. Number of nodes had significant positive $\mathrm{r}_{\mathrm{G}}(0.462 *)$ with the number of branches.

Genotypic and phenotypic variability, heritability and genetic advance as percent of mean (GAM \%)

The variances, coefficient of variations, heritability and genetic advance as percent of mean (GAM) are presented in Table 5.

\section{Genotypic and phenotypic variability}

The phenotypic variance was higher than the genotypic variance for all the traits. Highest phenotypic variance was observed for capsule number (2455.5) followed by capsule weight (1778.8) and seed yield (860.3). Lowest phenotypic variance was observed for number 
of branches (3.48). Similarly phenotypic coefficient of variation (PCV) was also higher than genotypic co-efficient of variation (GCV) for all the morphological and yield characters. The highest PCV was found for seed yield $(46.14 \%)$ followed by capsule weight $(44.86 \%)$ capsule number $(42.30 \%)$, number of branches $(32.50 \%)$ and number of nodes (23.85\%).

\section{Heritability}

High heritability was recorded for seed yield $(99.1 \%)$, followed by capsule number $(99.4 \%)$, capsule weight $(99.4 \%)$, number of nodes $(84.1 \%)$ and moderate heritability was observed for number of branches.

\section{Genetic advance as percent of mean (GAM $\%)$}

Genetic advance as percent of mean (GAM) was highest for capsule number (115.57\%), followed by seed yield $(94.17 \%)$, capsule weight $(91.88 \%)$, number of nodes $(41.22 \%)$ and number of branches (30.48\%). High heritability with high GAM was observed for capsule number, capsule weight, number of nodes $(84.1,41.22)$ and seed yield. High heritability with high GAM was also observed for. Moderate heritability with high GAM was observed for number of branches $(45.8,30.4)$.

The ANOVA for yield and its attributes revealed highly significant variability among the twenty three genotypes studied for all the five parameters viz., seed yield, number of primary branches, number of nodes, capsule number and capsule weight.

23 genotypes were classified for high, moderate and low yielding based on values obtained from seed yield. High yielding genotypes ranking from 1 to 7 were classified as high yielders and the yield ranged from107.4 $\mathrm{g} / \mathrm{pl}\left(1^{\text {st }}\right.$ rank) to $85.71 \mathrm{~g} / \mathrm{pl}$ (7th rank). Moderate yielding genotypes ranking 8 to 15 ranged from $79 \mathrm{~g} / \mathrm{pl}$ ( ${ }^{\text {th }}$ rank) to 52.63 $\mathrm{g} / \mathrm{pl}\left(15^{\text {th }}\right.$ rank). Low yielders ranking from 16 to 23 ranged from $44.34 \mathrm{~g} / \mathrm{pl}\left(16^{\text {th }}\right.$ rank $)$ to $8.88 \mathrm{~g} / \mathrm{pl}\left(23^{\text {rd }}\right.$ rank).

From CRC-1 to CRC-7, other than seed yield, out of the remaining four yield contributing characters studied, it was observed that for number of nodes, instead of 1 to 7 high ranks, it was observed that only $3^{\text {rd }}, 4^{\text {th }}$ and $6^{\text {th }}$ ranks were observed for CRC-1, CRC-3, CRC-4 respectively, while $1^{\text {st }}, 2^{\text {nd }}, 5^{\text {th }}$ and $7^{\text {th }}$ ranks are missing. However, for number of branches, $1^{\text {st }}, 3^{\text {rd }}, 4^{\text {th }}, 5^{\text {th }}$ and $7^{\text {th }}$ ranks are missing for CRC-1 to CRC-7. For capsule number, from CRC-1 to $\mathrm{CRC}-7,1^{\text {st }}$ to $8^{\text {th }}$ ranks were observed with $2^{\text {nd }}$ rank missing. Similarly, for capsule weight, from CRC-1 to CRC-7, it was observed that $7^{\text {th }}$ rank is missing.

From the above results, it was observed that CRC-4 is the only genotype where in the range for five characters was 2-6 ranks, thereby revealing that this is a desirable genotype with higher ranks for all the five characters studied. However, among the five characters studied, the top 1-7 ranks for the four characters was revealed by the genotypes CRC-1, CRC-2, CRC-3, CRC-5 revealing that these four genotypes were also desirable after CRC-4. These results showed that the above mentioned four genotypes were top rankers in four characters while for one character (viz., number of nodes) it was moderate. From the remaining high yielding genotypes viz., CRC6 and CRC-7, the results revealed that these genotypes showed top ranking from 1-7 only for one character viz., capsule weight for former while capsule number for the later respectively.

Similarly, for the genotypes CRC-8 to CRC15 , it was observed that CRC-8, CRC-9, CRC12, CRC-13 and CRC-14 ranked between 6 to 15 ranks (moderate) for all the three characters 
studied revealing them to be moderate genotypes. Whereas, CRC-10 was moderate for only three characters (viz., capsule number, capsule weight and number of nodes) and CRC-11 was also moderate for only three characters (viz., capsule number, capsule weight and number of branches) while CRC15 was moderate for only two characters studied (viz., capsule number\& capsule weight).

For the genotypes from CRC-16 to CRC-23, it was observed that all these genotypes ranked low (16-23) for two yield contributing characters i.e., both capsule number and capsule weight. While with number of nodes and number of branches the genotypes ranked variably with high, moderate and low rankings.

Hence, from the above results of all the genotypes for all the yield parameters studied, it has clearly indicated that the higher seed yield for all the genotypes was obtained due to their higher capsule weight followed by capsule number.

Maximum capsule weight/pl among the different varieties in castor were obtained due to genetic superiority and it even depends on weather conditions (Koutroubas et al., 1999). Koutroubas et al., $(1999,2000)$ suggested that lower number of branches in three spike orders resistant to shattering are desirable to develop new varieties in castor.

Golakia et al., (2015) reported that less number of nodes on main stem are the indirect indicators of earliness. Aswani et al., (2003) reported that capsule number is one of the yield contributing traits in castor. Patel et al., (2016) suggested that number of capsules can be taken into contemplation rather than number of nodes up to primary spike for improvements of seed yield in castor. Anastasi et al., (2015) opined that according to the variation in yield components of castor, seed yield has changed substantially with genotype. Gila and Manga (2015) reported that in castor seed yield/plant varies with the variety.

Uguru (2000) recorded range of 90.2 to 507.2 $\mathrm{g} / \mathrm{pl}$ of seed yield among six populations of castor. Gobin et al., (2001) reported that the mean seed yield ranged as from $500 \mathrm{~kg} / \mathrm{hain}$ India to $1000 \mathrm{~kg} / \mathrm{ha}$ in Thailand and 2500 $\mathrm{kg} / \mathrm{ha}$ under improved conditions in USA. However, recent report showed that $554 \mathrm{~kg} / \mathrm{ha}$ was obtained in Brazil, $600 \mathrm{~kg} / \mathrm{ha}$ in Russian Federations, $621 \mathrm{~kg} / \mathrm{ha}$ in Romania, $626 \mathrm{~kg} / \mathrm{ha}$ in Thailand, $667 \mathrm{~kg} / \mathrm{ha}$ in Sudan, $700 \mathrm{~kg} / \mathrm{ha}$ in Ukraine, $909 \mathrm{~kg} / \mathrm{ha}$ in China and 1,266 kg/ha in India (FAO, 2000).

About 878 accessions were identified among Indian collections for desirable traits with 7080 grams per 100 seed and high seed yield at multiple harvests (Anjani and Hegde, 2007). The average seed yields in India range from $1864 \mathrm{~kg} / \mathrm{ha}$ in the State of Gujarat to 371 $\mathrm{kg} /$ hain the State of Andhra Pradesh, where the crop has been predominantly grown without irrigation on marginal soils (Basappa, 2007).

In Brazil, seed yields have averaged $667 \mathrm{~kg} / \mathrm{ha}$ over the last $10 \mathrm{yr}$ (CONAB, 2011). The State of Parana has the highest average seed yield in the country $(1600 \mathrm{~kg} / \mathrm{ha})$ due to better soil fertility and agronomical practices (Silva et al., 2009).

A positive relationship between yield and its components indicates that any improvement in one of the yield components would result in concomitant increase in one or more components (Adeyanju et al., 2010). Both genotypic and phenotypic correlations were of comparable magnitude, the genotypic correlations of all the parameters studied were higher than the phenotypic correlations indicating that these characters were more related genotypically. 
Table.1 Weather data during crop growth period- Kharif-2012

\begin{tabular}{|c|c|c|c|c|}
\hline & \multicolumn{2}{|c|}{ Temperature } & \multicolumn{2}{|c|}{ RH (relative humidity) } \\
\hline & Max. $\left({ }^{\circ} \mathbf{C}\right)$ & Min. $\left({ }^{\circ} \mathbf{C}\right)$ & $\operatorname{Max}(\%)$ & $\operatorname{Min}(\%)$ \\
\hline Average & 30.4 & 18.7 & 89.0 & 54.0 \\
\hline Minimum & 15.2 & 10.2 & 59.0 & 17.0 \\
\hline Maximum & 40.0 & 25.5 & 100.0 & 96.0 \\
\hline
\end{tabular}

Table.2 Mean performance of yield and its components of 23 CRIDA castor genotypes during Kharif-2012

\begin{tabular}{|c|c|c|c|c|c|}
\hline Genotype & $\begin{array}{c}\text { Seed Yield } \\
(\mathbf{g} / \mathbf{p l}) \\
(\mathbf{R k})\end{array}$ & $\begin{array}{c}\text { Capsule } \\
\text { No./ pl } \\
\text { (Rk) }\end{array}$ & $\begin{array}{c}\text { Capsule } \\
\text { wt. (g/pl) } \\
\text { (Rk) }\end{array}$ & $\begin{array}{c}\text { Nodes } \\
\text { No./pl } \\
\text { (Rk) }\end{array}$ & $\begin{array}{c}\text { Branches } \\
\text { No./ pl } \\
\text { (Rk) }\end{array}$ \\
\hline CRC-1 & $107.40(1)$ & $174.50(3)$ & $150.00(2)$ & $24.3(3)$ & $5.56(13)$ \\
\hline CRC-2 & $106.44(2)$ & $182.50(2)$ & $147.80(4)$ & $18.0(13)$ & $7.50(2)$ \\
\hline CRC-3 & $104.92(3)$ & 172.75 & $147.10(5)$ & 24.1(4) & $6.06(11)$ \\
\hline CRC-4 & $94.36(4)$ & $167.33(5)$ & $148.10(3)$ & $22.3(6)$ & $7.50(2)$ \\
\hline CRC-5 & $93.85(5)$ & 225.00 & $151.80(1)$ & $16.0(15)$ & $6.75(6)$ \\
\hline CRC-6 & $92.12(6)$ & $145.50(8)$ & $133.00(6)$ & $11.8(18)$ & $3.00(20)$ \\
\hline CRC-7 & $85.71(7)$ & $146.25(7)$ & $127.50(8)$ & 19.7(11) & $4.83(16)$ \\
\hline CRC-8 & $79.00(8)$ & $163.25(6)$ & $127.80(7)$ & $16.0(15)$ & $6.00(12)$ \\
\hline CRC-9 & $75.89(9)$ & $130.20(9)$ & $113.80(9)$ & $16.8(14)$ & $7.04(5)$ \\
\hline CRC-10 & $74.85(10)$ & $118.8(10)$ & $100.10(10)$ & $18.7(12)$ & $4.33(17)$ \\
\hline CRC-11 & $64.15(11)$ & $108.72(13)$ & $90.50(13)$ & $15.8(16)$ & $5.00(15)$ \\
\hline CRC-12 & $63.92(12)$ & $110.57(11)$ & $80.80(15)$ & $25.3(2)$ & $6.33(9)$ \\
\hline CRC-13 & $62.45(13)$ & $109.67(12)$ & $92.10(12)$ & $16.0(15)$ & $7.16(4)$ \\
\hline CRC-14 & $58.80(14)$ & $106.50(14)$ & $94.50(11)$ & $19.8(10)$ & $6.17(10)$ \\
\hline CRC-15 & $52.63(15)$ & $103.78(15)$ & $83.00(14)$ & $15.9(17)$ & 4.09 (18) \\
\hline CRC-16 & $44.34(16)$ & 77.67 (18) & $64.11(16)$ & $20.8(7)$ & 2.79 (21) \\
\hline CRC-17 & $41.83(17)$ & 99.46 (16) & $59.10(17)$ & $28.2(1)$ & $7.30(3)$ \\
\hline CRC-18 & 34.57 (18) & $45.11(22)$ & $42.00(21)$ & $20.5(8)$ & $5.14(14)$ \\
\hline CRC-19 & 34.00 (19) & $58.03(21)$ & $46.90(20)$ & $18.0(13)$ & $3.33(19)$ \\
\hline CRC-20 & $30.92(20)$ & $62.00(20)$ & $50.30(18)$ & $11.0(19)$ & $5.00(15)$ \\
\hline CRC-21 & $25.98(21)$ & 77.17 (19) & 48.40 (19) & $23.2(5)$ & $6.72(7)$ \\
\hline CRC-22 & $25.04(22)$ & $82.83(17)$ & 48.40 (19) & $22.3(6)$ & $7.75(1)$ \\
\hline CRC-23 & $8.88(23)$ & $26.50(23)$ & $15.00(22)$ & $25.3(2)$ & $6.67(8)$ \\
\hline Average & 63.57 & 117.13 & 94.01 & 19.55 & 5.74 \\
\hline Minimum & 8.88 & 26.5 & 15.0 & 11.0 & 2.79 \\
\hline Maximum & 107.4 & 225.0 & 151.8 & 28.2 & 7.75 \\
\hline
\end{tabular}

1to7 ranks-high, 8 to15 ranks-moderate, 16 to 23 ranks -low 
Table.3 ANOVA for yield and yield parameters of 23 castor genotypes during Kharif-2012

\begin{tabular}{|l|l|l|l|l|l|l|}
\hline & & \multicolumn{5}{c|}{ Mean sum of squares } \\
\hline \multicolumn{1}{|c|}{ Source } & DF & Seed yield & \multicolumn{1}{c|}{$\begin{array}{c}\text { Capsule } \\
\text { number }\end{array}$} & $\begin{array}{c}\text { Capsule } \\
\text { weight }\end{array}$ & $\begin{array}{c}\text { Number of } \\
\text { nodes }\end{array}$ & $\begin{array}{c}\text { Number of } \\
\text { branches }\end{array}$ \\
\hline Replication & 2 & 9.729 & 37.246 & 1.247 & 3.291 & 0.355 \\
\hline Genotype & 12 & $2565.4^{* *}$ & $7336.8^{* *}$ & $5316.4^{* *}$ & $58.4^{* *}$ & $6.670^{* *}$ \\
\hline Error & 24 & 7.766 & 14.879 & 9.934 & 3.469 & 1.887 \\
\hline CV (\%) & & 4.38 & 3.29 & 3.35 & 9.52 & 23.93 \\
\hline
\end{tabular}

$*$ Significance at $\mathrm{p}<0.05$ and $* *$ Significance at $\mathrm{p}<0.01$

Table.4 Genotypic and phenotypic correlations of 23 CRIDA castor genotypes during Kharif2012

\begin{tabular}{|c|c|c|c|c|c|c|}
\hline & & Seed yield & $\begin{array}{l}\text { Capsule } \\
\text { number }\end{array}$ & $\begin{array}{c}\text { Capsule } \\
\text { weight }\end{array}$ & $\begin{array}{l}\text { No. of } \\
\text { nodes }\end{array}$ & $\begin{array}{c}\text { No. of } \\
\text { branches }\end{array}$ \\
\hline \multirow{2}{*}{$\begin{array}{l}\text { No. of } \\
\text { nodes }\end{array}$} & $\mathbf{r}_{\mathrm{G}}$ & -0.162 & -0.140 & -0.206 & 1.00 & $0.462 *$ \\
\hline & $\mathbf{r}_{\mathbf{P}}$ & -0.143 & -0.122 & -0.188 & 1.00 & 0.337 \\
\hline \multirow{2}{*}{$\begin{array}{l}\text { No. of } \\
\text { branches }\end{array}$} & $\mathbf{r}_{\mathrm{G}}$ & 0.069 & 0.266 & 0.122 & & 1.00 \\
\hline & $\mathbf{r}_{\mathbf{P}}$ & 0.046 & 0.192 & 0.103 & & 1.00 \\
\hline \multirow{2}{*}{$\begin{array}{l}\text { Capsule } \\
\text { number }\end{array}$} & $\mathbf{r}_{\mathrm{G}}$ & $0.930 * *$ & 1.00 & $0.965 * *$ & & \\
\hline & $\mathbf{r}_{\mathbf{P}}$ & $0.924 * *$ & 1.00 & $0.959 * *$ & & \\
\hline \multirow{2}{*}{$\begin{array}{l}\text { Capsule } \\
\text { weight }\end{array}$} & $\mathbf{r}_{\mathrm{G}}$ & $0.985 * *$ & & 1.00 & & \\
\hline & $\mathbf{r}_{\mathbf{P}}$ & $0.979 * *$ & & 1.00 & & \\
\hline \multirow[t]{2}{*}{ Seed yield } & $\mathbf{r}_{G}$ & 1.00 & & & & \\
\hline & $\mathbf{r}_{\mathbf{P}}$ & 1.00 & & & & \\
\hline
\end{tabular}

*Significance at $\mathrm{p}<0.05$ and $* *$ Significance at $\mathrm{p}<0.01$

Table.5 Co-efficient of variations, variances, heritability and GAM (\%) for yield and yield parameters of 23 CRIDA castor genotypes during Kharif-2012

\begin{tabular}{|l|l|l|l|l|l|l|}
\hline \multicolumn{1}{|c|}{ Parameter } & $\begin{array}{l}\text { Genotypic } \\
\text { variance }\end{array}$ & $\begin{array}{l}\text { Phenotypic } \\
\text { variance }\end{array}$ & GCV & PCV & Heritability & $\begin{array}{c}\text { GAM } \\
\text { (\%) }\end{array}$ \\
\hline Seed Yield & 852.6 & 860.3 & 45.93 & 46.14 & 0.991 & 94.17 \\
\hline $\begin{array}{l}\text { Capsule } \\
\text { Number }\end{array}$ & 2440.6 & 2455.5 & 42.17 & 42.30 & 0.994 & 115.57 \\
\hline $\begin{array}{l}\text { Capsule } \\
\text { Weight }\end{array}$ & 1768.8 & 1778.8 & 44.73 & 44.86 & 0.994 & 91.88 \\
\hline $\begin{array}{l}\text { No. of Nodes } \\
\text { No. of } \\
\text { Branches }\end{array}$ & 18.30 & 21.78 & 21.87 & 23.85 & 0.841 & 41.22 \\
\hline
\end{tabular}


The $r_{G}$ and $r_{P}$ of seed yield was highly significantly and positively correlated for both capsule weight $(0.985 * *$ and $0.979 * *)$ and capsule number $\left(0.930^{* *}\right.$ and $\left.0.924^{* *}\right)$ which were in concurrence with the results of Ahmed et al., (2012). Similarly, in the present investigation, seed yield and number of primary branches are correlated nonsignificantly and these results are in agreement with the findings of Aghili et al., (2012) in Lentil. However, Sarwar et al., (2010) reported seed yield in castor had nonsignificant correlation with number of nodes. Positive and significant genotypic correlation was observed with number of nodes with number of branches (Abimiku et al., 2012) in castor.

Improvement of castor seed yield can therefore, be achieved through selection of these highly correlated characters as increase in mean value of any one of these characters would significantly increase the mean of others (Patel et al., 2016). The variations that existed among the genotypes in the yield components showed that in castor, seed yield could be improved through selection programmes, if genetic information of these characters is known (Gila and Manga, 2015).

While, looking into the estimates of GCV and $\mathrm{PCV}$, it was observed that PCV was greater than GCV indicating the influence of environment and hence phenotypic selection can also be effectively useful for the crop improvement (Patel et al., 2010). Higher GCV and PCV were observed for capsule number (2440.6 \& 2455.5) followed by capsule weight (1768.8 \& 1778.8) and seed yield (852.6\& 860.3). Higher GCV and PCV for seed yield, capsule number and capsule weight in castor were reported by Udaya et al., (2013) and Lakshmamma et al., (2005).

Heritability estimates along with genetic gains are more effective and reliable in predicting the improvement through selection (Johnson et al., 1955). Heritability which denotes the proportion of genetically controlled variability is very important biometrical tool for guiding plant breeder for adoption of appropriate breeding procedures. The heritability value indicates the presence of additive gene action and further improvement in these traits could be effective through direct selection (Jaimini, 2002). High heritability coupled with high genetic advance, indicate the presence of high additive gene effects suggesting that direct selection for the traits would be beneficial (Panse, 1957). High heritability coupled with moderate genetic advance in the character indicates that the variability was due to both additive and non-additive interaction of genes. The characters exhibited low heritability with moderate genetic advances indicates a non-additive gene effect in governing the characters. Low heritability with low genetic advance indicate the preponderance of non-additive gene action in inheritance of the characters and high influence of environment (John et al., 2016).

High heritability with high genetic advance as mean (GAM) was observed for capsule number, capsule weight and seed yield. These results are in accordance with the findings of Dhapke et al., (1992), Solanki and Joshi (2000) with castor. Similarly high heritability with high genetic advance mean was also observed for number of nodes. Dorairaj et al., (1973) reported high heritability with high genetic advance mean for number of nodes in castor. Plant traits having high variability, high heritability and genetic advance mean would be an effective tool for crop improvement (Aytac and Kinaci, 2009). Hence, for the improvement of seed yield in castor, selection for capsule number and capsule weight could be given priority (Mehta and Vashi, 1998). The emphasis of current breeding programmes in India is mainly 
focused on high seed yield in castor (Lavanya et al., 2006; Lavanya and Solanki, 2010) since seed yield is the principal and predominant factor for the development of an ideal genotype, identification of significant yield contributing parameters are necessary for sustaining improved yield (Halilu et al., 2013). Increased interaction between plant breeders and geneticists with supporting scientists such as molecular biologists, plant physiologists, plant nutritionists, entomologists, and plant pathologists would speed the genetic improvement of castor (Severino et al., 2012). Hence, these results revealed that capsule number and capsule weight are the most important traits for the improvement of seed yield in castor.

Hence, these results revealed that capsule number and capsule weight are the most important traits for the improvement of seed yield in castor.

In conclusion, twelve genotypes, out of 23 CRIDA genotypes were selected which yielded above the average yield of $63.57 \mathrm{~g} / \mathrm{pl}$ for further evaluation. It was observed that CRC-4 is the only genotype where in the range for five characters was 2-6 ranks, thereby revealing that this is a desirable genotype with higher ranks for all the five characters studied. The development of new castor cultivars would be enhanced by selecting capsule weight and capsule number for increasing seed yield.

\section{Acknowledgements}

We acknowledge the Director, CRIDA and Head, Division of Crop Sciences for providing both field and lab facilities to conduct experiments.

\section{References}

Abimiku, O.E., E.D. Azagaku, E. Ndor, 2012. Genetic Variability and Correlation
Studies in Some Quantitative Characters in Castor (Ricinus communis L.) Accessions. Asian J. Agric. Sci4(6): 368372.

Adeyanju, A.O., A.Usman, S.G. Mohammed, 2010. Genetic Correlation and Pathcoefficient Analysis of Oil Yield and its Components in Castor. Int. J. Appl. Agri. Res. 5(2): 243-250.

Aghili, P., A.A. Imani, H. Shahbazi, Y. Alaei, 2012. Study of correlation and relationships between seed yield and yield components in Lentil (Lens culinaris Medik). Ann. Biol. Res. 3 (11):50425045.

Ahmed H.M., G. Sarwar, M.A. Haq, 2012. Genetic variability and interdependence of morphological traits in castor bean (Ricinus communis L.) mutants. Song. J. Sci. Tech. 34(3): 279-286.

Anastasi U., O. Sortino, S.L. Cosentino, C. Patanè, 2015. Seed yield and oil quality of perennial castor bean in a Mediterranean environment. Int. J. Pl. Prod. 9 (1): 99-116.

Anjani, K., D.M. Hegde, 2007. Biodiversity in indigenous castor. In: Kannaiyan $\mathrm{S}$, Venkatarmana K (Eds.), National Consultation Workshop on Agrobiodiversity Hot Spots and Access and Benefit Sharing, pp. 42.

Aswani, K., R.S. Sangwan, D.S. Jatasra, 2003. Correlation and path coefficient analysis in castor (Ricinus communis L.) under dryland conditions. Ind. J. Dryland Agri. Res. Dev. 18: 89-91.

Aytac, Z.,G., Kinaci, 2009. Genetic variability and association studies of some quantitative characters in winter rapeseed (Brassica napus L.). Afr. J. Biotech. 8(15):3547-3554.

Basappa, H., 2007. Validation of integrated pest management modules for castor (Ricinus communis) in Andra Pradesh. Ind. J. Agri. Sci. 77:357-362.

CONAB 2011. Série histórica de safras: Mamona. Companhia Brasileira de Abastecimento, Brazil. http://www.conab. gov.br. 
Dapke, J.S., M.R., Naik, G.B., Vaidya, P.B., Vanve, A.V., Narwade,B.K., Rajkumar, 2016. Genetic variability in castor (Ricinus communis L.) European. J. of Biotechnol. Biosci. 4(4): 39-40.

Dhapke, S.K., P.W., Khorgade, M.N., Narkhede, 1992. Estimation of genetic variability in castor (Ricinus communis L.). Agri. Sci. Dig. 12:141-143.

Dhedhi, K.K., Y.H., Ghelani, H.J., Joshi, C.J., Dangaria, 2010. Correlation and path coefficient analysis in castor (Ricinus communis L.) over environments. Agri. Sci. Dig. 30(4): 286- 289.

Dorairaj S.M., M., Kandasami., S. Palaniswamy, S., Varisai, 1973. Correlation studies in Ricinus communis L. within inbreds and hybrids. Madras Agric. 60 (9-12): 1481-1485.

FAO 2000. Castor: FAOSTAT. Statistical Database Results 2000. Giriraj K, Mensikai SW, Sindagi SS 1973.

Frageria M.S., and Kokli, U.K. 1997. Correlation studies in tomato. Haryana J. Hort. Sci. 25: 158-160.

Gila, N., A.G., Manga, 2015. Evaluation of yield and yield components of castor (Ricinus communis L.) germplasm from rain forest and southern guinea savannah agro-ecological zones of Int. J. of Curr. Res. Acad. Rev. 3(6): 366-373.

Gobin, A.M.I., M.I., Uguru, J., Deckers, 2001. Oil crop. In: Crop production in tropical Africa. Romain H. Raemaekers (Ed.). Brussels Belgium Director General for International co-operation. pp. 725-733.

Golakia, P.R., V.K., Poshiya, B.A., Monpara, 2015. Identification of superior donor parents for earliness through combining ability in castor. Int. J. Res. in Plant Sci. 5(3): 26-31.

Halilu, A.D., D.A. Aba and J.O. Ogunwole, 2013. Genetic variability, genetic gain and relationships of yield and yield components in castor (Ricinus communis L.). Res. Rev. in BioSci. 7(5): 181-186.

Hinckley, A.C. 2006. Genotyping and bioforensics of Ricinus communis. Lawrence Livermore National
Laboratory. UCRL-TH-226437.

Jaimini, N., 2002. Genetic variability, association studies, genetic divergence and stability analysis in newly evolved pistillate lines of castor (Ricinus communis L.). M.Sc. (Ag.) Thesis, Gujarat Agricultural University, Sardarkrushinagar (Gujarat).

John, K. and P. Raghava Reddy, 2016. Studies on genetic parameters for yield and yield attributes in groundnut (Arachis hypogaea L.). Int. J. Recent Sci. Res. 7(5): 1115411156.

Johnson, H.W., H.E. Robinson and R.E., Comstock, 1955. Estimates of genetic and environmental variability in soybean. Agron. J. 47: 314-318.

Koutroubas S.D., D.K., Papakost, A., Doitsinis, 2000. Water requirements for castor oil crop (Ricinus communis L) in a Mediterranean climate. J. Agron. Crop Sci. 184: 33-41.

Koutroubas, S.D., D.K. Papakosta, A., Doitsinis, 1999. Adaptation and yielding ability of castor plant (Ricinus communis L.) genotypes in a Mediterranean climate. Eur. J. Agron. 11: 227-237

Lakshmamma, P., P. Lakshmi, Y. Chandra Mohan, C. Lavanya, 2005. Genetic variability and character association in castor (Ricinus communis L.). Natl. J. Plant Improv. 7(2): 122-126.

Lavanya, C., S.S. Solanki, 2010. Crop improvement of castor. The challenges ahead In: Hegde DM. (Ed.). Research and development in castor. Present status and future strategies. Indian Society of Oilseeds Research, Hyderabad.

Lavanya, C., P.V.R. Rao, V.V. Gopinath, 2006. Studies on combining ability and heterosis for seed yield and yield components in castor (Ricinus communis L.) hybrids. J. Oil Seeds Res. 23:174-177.

Mehta, D.R., P.S. Vashi, 1998. Correlation and path analysis of seed yield and its components in castor. Ind. J. Agric. Res. 32(3):160-164.

Nagesh Kumar, M.V., V. Gouri Shankar, V. Ramya, P. Bindu Priya, A.V. 
Ramanjaneyulu, G. Seshu, D. Vishnu Vardhan Reddy, 2015. Enhancing castor (Ricinus communis L.) productivity through genetic improvement for Fusarium wilt resistance-a review. Ind. Crops Prod. 67:330-335.

Panse, V.G., 1957. Genetic of quantitative character in selection plant breeding. Ind. J. Gen. 17: 318-328.

Patel, J.K., D.B. Nakarani, 2016. Character association and path analysis in castor (Ricinus communis L.). Int. J. Agri. Sci. 12(1): 22-27.

Patel, J.R., M.P. Saiyed, C.G. Patel, R.K. Bhatt, J.P. Bhatt, 2010. Genetic variability and correlation studies in castor (Ricinus communis L.). Int. J. Agri. Sci. 6(1): 129131.

Patel P.S., S.N., Jaimini, 1988. Variability in castor (Ricinus communis L.). Ind. J. Agri. Sci. 58 (5): 394-396.

Ramesh, T., A. Siva Sankar, J. Sreelakshmi, P. Gouthami, C. Leela, Ch.V. Durga Rani, V. Gouri Shankar, B. Lavanya, P. Narayana Reddy, M.Y. Dudhe 2016. Utilization of in silico EST-SSR markers for diversity studies in castor (Ricinus communis L.). Physiol. Mol. Biol. Plants. DOI 10.1007/s12298-016-0367-x.

Sarwar, G., H.M. Ahmed, J. Hussain, 2010. Evaluation of castor bean (Ricinus communis L.) mutants for genetic parameters and cluster analysis. J. Agri. Res. 48(3): 289-301.

Severino, L.S., D.L. Auld, M. Baldanzi, M.J.D. Candido, G. Chen, W. Crosby, X. He, D. Tan, P. Lakshmamma, C. Lavanya, O.L.T. Machado, T. Mielke, M. Milani, T.D., Miller, J.B. Morris, S.A. Morse, A.A. Navas, D.J. Soares, V. Sofiatti, M.L., Wang, M.D., Zanotto, H., Zieler, 2012. A Review on the Challenges for Increased Production of Castor. Agron. J. 104:853-880.

Silva, G.H., M.S.T. Esperancini, C.O. Melo, O.C. Bueno, 2009. Production cost and profitability of the castor oil plant in western Paraná State. Informações Econômicas 39:85-92.

Solanki, S.S., P. Joshi, 2000. Combining ability analysis over environments of diverse pistillate and male parents for seed yield and other traits in castor (Ricinus communis L.). Indian J. Genet. Pl. Br. 60: 201-212.

Udaya Bhanu, K., V. Satyanarayana Rao, M. Srinivasa Rao, 2013. Genetic variability in castor (Ricinus communis L.) for yield and its contributing traits. Int. J Food, Agric. Vet. Sci. 3(3): 103-108

Uguru, M.I., 2000. Genetic variability and breeding value of castor genotypes. Agron. Sci.1(1): 130-135.

\section{How to cite this article:}

Sowmya, P., M. Vanaja, V. Sunita and Raghuram Reddy, P. 2019. Variability and Genetic Advance for Seed Yield and its Components in Castor (Ricinus communis L.) Germplasm of CRIDA under Rain-Fed Conditions in Alfisols. Int.J.Curr.Microbiol.App.Sci. 8(01): 20012011. doi: https://doi.org/10.20546/ijcmas.2019.801.210 